\title{
Deiksis dalam Cerpen "Senyum Karyamin" karya Ahmad Tohari sebagai Materi Pembelajaran dalam Bahasa Indonesia
}

\author{
Chelfia Luthfi Intan Pratiwi ${ }^{1, *}$ Asep Purwo Yudi Utomo ${ }^{2}$ \\ Universitas Negeri Semarang ${ }^{1,2}$ \\ *Corresponding author: email: chelfiap9@gmail.com
}

Submitted: 5 June 2021

Revised: 3 July 2021

Accepted: 7 July 2021

\begin{abstract}
The problem of deixis is an obstacle in understanding reading texts, especially literary works. This study aims to identify and describe deixis in short story literary works. In addition, the findings of this study aim to be a medium in Indonesian language learning activities, especially in text description material. This research is a qualitative research with descriptive method. The data collection method is observational note-taking. The technique of analyzing the data used in this study is to use the data analysis technique of the Miles and Huberman model. Based on the research findings, there are five types of deixis in the Senyum Karyamin short story, namely person, place, time, discourse, and social. Through the identification of this deixis, learning to understand descriptive text will be easier to implement.
\end{abstract}

Keywords: pragmatics, deixis, short story

Abstrak. Masalah deiksis menjadi kendala dalam memahami teks bacaan, khususnya teks karya sastra. Penelitian ini bertujuan untuk mengidentifikasi dan mendeskripsikan deiksis dalam karya sastra cerpen. Selain itu, temuan penelitian ini bertujuan untuk menjadi media dalam kegiatan pembelajaran bahasa Indonesia khususnya pada materi teks deskripsi. Penelitian ini merupakan penelitian kualitatif dengan metode deskriptif. Metode pengumpulan datanya adalah simak-catat. Teknik analisis data yang digunakan dalam penelitian ini adalah dengan menggunakan teknik analisis data model Miles dan Huberman. Berdasarkan hasil penelitian, terdapat lima jenis deiksis dalam cerpen Senyum Karyamin, yaitu orang, tempat, waktu, wacana, dan sosial. Melalui identifikasi deiksis ini, pembelajaran memahami teks deskriptif akan lebih mudah dilaksanakan.

Keywords: pragmatik, deiksis, cerpen.

\section{Pendahuluan}

Dalam kehidupan manusia, bahasa memiliki peran dan posisi yang sangat penting. Sebagai alat komunikasi, bahasa Indonesia memiliki beberapa aspek keterampilan yang perlu diperhatikan. Dari aspek tersebut terdapat adanya empat aspek keterampilan mulai dari keterampilan menulis, keterampilan berbicara, keterampilan membaca, hingga keterampilan menyimak. Dalam berkomunikasi sehari-haro, keempat keterampilan tersebut tidak dapat dipisahkan (Rohmadi, 2014). Menurut Tologana (2016) bahasa sebagai suatu bentuk hal yang hakiki dalam kehidupan manusia. Hal tersebut diartikan bahwa pentingnya peran dan posisi 
bahasa Indonesia karena sebagai jembatan setiap manusia dalam melakukan kegiatan komunikasi dengan masyarakat yang ada di sekitar dalam setiap harinya. Manusia ialah makhluk hidup yang hidup dalam suatu lingkungan sebagai individu yang saling terhubung (Nadzifah \& Asep, 2020). Dari segi penggunaannya, bahasa dapat digunakan sebagai media untuk berinteraksi serta berekspresi baik secara tertulis maupun secara lisan (Wicaksono, 2019). Menurut Rahardi (2005) sosok fungsi bahasa sendiri pada dasarnya dinyatakan secara konkret dalam tindak tutur (speech acts). Sebuah komunikasi akan dapat berjalan dengan baik, yang mana artinya dari hal tersebut dapat ditandai dengan pesan atau maksud oleh seorang penutur sampaikan dapat diterma dan tersampaikan pada lawan bicaranya. Manusia dilahirkan dengan kodrat bahwa harus beradaptasi serta berhubungan sosial dengan masyarakat di lingkungan sekitarnya (Megawati, 2012). Indonesia merupakan bangsa yang berbudi ;uhur serta bersahaja (Setyawati, 2013). Suatu komunikasi dapat berjalan dengan baik apabila lawan bicara yang terlibat dalam suatu komunikasi tersebut apabila bahasa yang digunakan terjadi pada sasaran yang tepat. Artinya, dalam hal ini bahwa bahasa digunakan sesuai dalam situasi serta kondiri seorang penutur melakukan komunikasi. Selain itu, hal tersebut juga dipengaruhi oleh suatu faktor yang menentukan dalam suatu interaksi yaitu adanya seorang lawan bicara, tujuan dilakukannya pembicaraan, bentuk permasalahan yang menjadi pembicaraan serta keadaa atau situasi. Penggunaan bahasa tersebut dinamakan dengan sebutan pragmatik.

Secara umum, salah satu bentuk cabang ilmu bahasa yang membahasa mengenai bahasa berdasarkan eksternal serta penggunaan satuan bahasa digunakan dalam berkomunikasi disebut dengan Pragmatik (Junianto 2010). Suatu makna dalam hubungan dengan penggunan suatu bahasa seorang penutur yang lebih luas dengan situasu ujar diberikan dalam kajian pragmatik (Jayati 2018). Setiap suatu tuturan tidak dapat hanya memiliki makna satu tuturan saja. Namun, dalam suatu tuturan terkadang memiliki lebih dari satu maksud didalamnya (Kusumawardani, 2017). Sebagai akibatnya, dari pernyataan tersbeut studi pragmatik terkadang dihubungkan mengenai analisis perihal oleh seseorang dengan tuturan-tuturannya daripada adanya suatu pisahan makna yang terdapat pada suatu frasa ataupun kata yang biasanya digunakan dalam suatu bentuk tuturan tersebut. Hal tersebut dikarenakan pada pragmatik banyak mempelajarai mengenai perihal makna yang mana terdapat pada bahasa secara tersirat. Dalam linguistik sebagai bentuk tataranya, pragmatik adalah tataran yang mempertimbangkan pengguna bahasa dengan manusia sebagai tokohnya. Meskipun pragmatik dengan semantik pengkajiannya sama yaitu membahas mengenai makna, namun makna yang pengkajian makna diantara keduanya berbeda (Fitriani, 2019).

Dalam cabang ilmu pragmatik, terdapat ilmu yang membahas mengenai arah acuan yang disebut deiksis dalam suatu satuan bahasa. Dalam bahasa Yunani, deiksis yaitu "menunjukkan atau menunjuk" (Nasution 2012). Deiksis merupakan bagian dari pragmatik. Deiksis sendiri sering disebut bahwa bentuk suatu bahasa yang mempunyai suatu fungsi sebagai penunjuk yang mana berupa kata atau yang lain yang dapat berpindah-pindah posisinya sesuai pada konteksnya. Alwi (2003) menyatakan bahwa deiksis ialah bentuk suatu perihal semantik yang ada dalam penafsiran dari konstruksi dengan menurut situasi seorang pembicara sebagai acuannya. Dalam penjelasan tersebut suatu konstruksi ataupun kata bersifat deiksis. Berdasarkan pernyataan tersebut, deiksis merupakan suatu kata yang memiliki berpacu pada pembicara, tempat, waktu seorang pembicara bertutur. Sehingga, sebuah kata dapat dikatakan memiliki makna deiksis apabila memiliki aspek salah satu dari kalimat ataupun kata tersebut bergantung pada perubaan konteksnya. Hal tersebut berlaku pada semua bentuk deiksis. Deiksis sendiri terdapat beberapa jenis yaitu deiksis orang (persona), deiksis waktu (time), deiksis tempat (place), deiksis wacana (discourse), dan deiksis sosial (social). Akan ada sanksi yang diterima oleh seseorang dalam hidup di masyarakat apabila menggunakan bahasa yang tidak sesuai dengan aturan sosial budaya hidup di masyarakat mulai dari mendapat labeling sebagai orang yang sombong, angkuh, egois, tidak beretika hingga tidak berbudaya (Yuliana 2013). Apabila diliat dari perkembangan zaman, tentu kehidupan masyarakat dari masa ke masa sangat 
berbeda. Hal tersebut dikarenakan oleh adanya pengaruh adat istiadat pada perkembanan zaman keidupan masyarakat (Purwoningrum 2013).

Cerita pendek merupakan jenis salah satu karya sastra Indonesia yan memiliki khas bahwa di dalamnya memiliki unsur kata yang sangat erat berhubungan dengan kondisi sosial penulisnya, sala satu diantaranya tentu dapat dilihat pada segi aspek deiksis sosialnya (Mulyati, 2019). Analisis deiksis pada cerita pendek "Senyum Karyamin" karya Ahmad Tohari dilatar belakangi dengan penggunaan deiksis dalam karya sastra. Dalam suatu karya sastra tentu terdapat adanya penggunaan gaya bahasa yang digunakan untuk menunjukkan perihal waktu, tempat, wacana, ataupun keadaan sosial seseorang. Penggunaan gaya bahasa yang bahkan pada biasanya digunakan dengan kata ganti membuat pembaca kesulitan untuk memahami tentang apa cerita tersebut dibahas atau pesan apa yang ingin disampaikan penulis dalam cerita tersebut untuk pembaca. Sehinga, hal tersebutlah yang menjadikan dilakukannya analisis deiksis untuk mengetahui maksud dari suatu bacan cerita. Sebagai objek yang akan dikaji dalam hal ini adalah cerpen "Senyum Karyamin" karya Ahmad Tohari.

Penelitian mengenai analisis deikisis pada suatu karya sastra dirasa sangat dibutuhkan. Dalam suatu karya sastra novel ataupun cerpen akan selalu muncul deiksis di dalamnya, seina al ini sanat pentin untuk dilakukan penkajian serta dipelajari sebab aspek tersebut berkaitan erat denan pembelajaran sastra kususnya pada waktu, latar, serta persona dalam karya sastra (Agustiyan, 2012). Hal tersebut tentu untuk memudahkan penikmat sastra terutama agar lebih mudah dalam memahami suatu karya sehingga agar tidak terjadi adanya kesalahpahaman dalam penerimaan maksud pesan yang ingin dismapaikan dalam suatu karya. Selain itu, tujuan penelitian berikut sebagai salah satu media pembelajaran dalam bahasa Indonesia. (Narayukti 2020) mengungkapkan untuk memahami bahasa saat berkomunikasi seseoran diaruskan dapat memaami suatu bentuk konteks dalam situasi dalam penunaan baasa tersebut. Dalam pembelajarn bahasa Indonesia, pemahaman mengenai suatu bacaan sangat dibutuhkan untuk dapat memahami setiap materi yang akan diceritakan kembali. Dalam hal ini dirasa cocok untuk dijadikan sebagia media pembelajaran kususnya dalam mata pelajaran bahasa Indonesia dlaam memahami bacaan lalu kemudian menganalisis bacaan tersebut untuk memamahami makna dalam bacaan cerita tersebut. Sehingga, diharap adanya penelitian ini akan membantu masyarakat untuk lebih memudahkan mendapatkan pemehaman bagaimana cara memahami maksud dalam suatu bacaan serta dapat menggunakan hasil dari analisis ini sebagia salah satu contoh untuk media pembelajaran bahasa Indonesia. Salah satu diantaranya yaitu dalam pembelajaran bahasa Indonesia materi deskripsi.

\section{Metode}

Penelitian ini tergolong kepada penelitian kualitatif. Pendekatan kualitatif merupakan bentuk pendekatan penelitian yang dilakukan dengan menyajikan data hasil penelitian yang dilakukan dalam bentuk deskriptif yang disertai dengan sumber dan hal-hal lain yang mendukung dalam proses kegiatan penelitian. Analisis dalam pendekatan kualitatif ini akan dilakukan dengan teknik pengolahan data analisis deskriptif. Data dalam kegiatan analisis ini berupa dokumen dengan bentuk kalimat yang memiliki deiksis pada cerpen "Senyum Karyamin" karya Ahmad Tohari. Agar mendapat data tersebut dilakukan adanya dokumentasi. Data yang sudah didapatkan akan dilakukan analisis dengan melalui tabel-tabel kemudian dilakukan langkah menganalisis deiksis sesuai denga distribusinya (Suparno, 2015). Hal tersebut agar mampu menjawab serta menjelaskan permasalahan yang akan dikaji yang terdapat pada rumusan masalah yang telah ditentukan di awal yaitu untuk menentukan kalimat-kalimat yang tergolong dalam kalimat berjenis deiksis sesuai dengan jenis-jenis deiksisnya.

Dalam melakukan analisis ini, terdapat beberapa langkah yang harus dilakukan. Yang mana langkah awal yang harus disiapkan tentu saja bahan bacaan yang akan dilakukan analisis. Bahan bacaan yang akan dikaji pada analisis ini yaitu cerpen "Senyum Karyamin" karya Ahmad Tohari. Kemudian setelah itu akan dilakukan pendataan bagian-bagian atau kalimat yang dirasa 
masuk pada golongan deiksis. Deiksis sendiri memiliki beberapa jenis. Sehingga, dalam pendataan tersebut akan digolongkan berdasarkan jenis-jenis deiksis itu sendiri. Untuk memudahkan dalam melakukan analisis maka pengkaji akan melakukan pemberian nomor atau kode yang pada data atau kalimat yang mengandung deiksis yaitu pemberian nomor data dan halaman pada cerpen. Selanjutnya pada langkah terakhir akan dilakukan adanya tahap menganalisis. Dalam tahap menganalisis ini bertujuan untuk menentukan pada data kalimatkalimat sesuai dengan jenis-jenis deiksis. Adapun teknik menganalisis data yang dipakai dalam penelitian ini adalah dengan menggunakan teknik analisis data model Miles dan Huberman. Teknik tersebut banyak digunakan dalam setiap pengkajian berupa penelitian kualitatif. Miles dan Huberman (dalam Merentek, 2006) mengemukakan beberapa tahap dalam kegiatan menganalisis data, yaitu (1) data reduction (reduksi data), (2) data display (penyajian data), dan (3) conclusion drawing/verification (penarikan kesimpulan).

Mereduksi data artinya memilih hal-hal penting yang menjadi fokus permasalahan dalam suatu hal yang akan diteliti dan menyingkirkan hal-hal tidak diperlukan. Fokus data dalam penelitian ini fokus denan bentuk kaimat yang mengandung deiksis pada bacaan cerpen "Senyum Karyamin" karya Ahmad Tohari. Data yan sudah terkumpul akan dijelaskan dengan bentuk deskripsis. Setelah seluruh tahapan telah dilalui, dalam penelitian ini akan dilakukan penarikan kesimpulan. Dalam penarikan kesimpulan ini harus dapat menjawab pertanyaan atau topic permasalahan yang terdapat pada rumusan masalah yang telah dikaji atau yang telah dibahas dalam hasil dan pembahasan.

\section{Hasil dan Pembahasan}

Analisis deiksis pada cerpen "Senyum Karyamin" karya Ahmad Tohari dianalisis berdasarkan jenis-jenis deiksis. Pada kajian analisis pragmatik, terdapat beberapa jenis deiksis diantaranya deiksis persona, tempat, waktu, wacana, dan sosial. dalam cerpen tersebut ditemukan 4 deiksis persona, 2 deiksis tempat, 3 deiksis waktu, 4 deiksis wacana, dan 2 deiksis sosial.

Tabel 1. Bentuk deiksis dalam cerpen "Senyum Karyamin” karya Ahmad Tohari.

\begin{tabular}{|l|l|c|}
\hline No & \multicolumn{1}{|c|}{ Jenis Deiksis } & Jumlah Kemunculan \\
\hline 1 & Deikisis Persona & 4 \\
\hline 2 & Deiksis Tempat & 2 \\
\hline 3 & Deiksis Waktu & 3 \\
\hline 4 & Deksis Wacana & 4 \\
\hline 5 & Deiksis Sosial & 2 \\
\hline
\end{tabular}

\section{Deiksis Persona dalam Tuturan Cerpen "Senyum Karyamin” Karya Ahmad Tohari}

Pada jenis deiksis persona yaitu menjelaskan pada peran adanya pihak partisipan pada kejadian tindak tutur dengan mitra tuturnya mengenai hal yang dibicarakan dan identitas yang hal dibahas serta identitas lainnya. Deiksis ini adalah bentuk deiksis yang asli, berbeda pada jenis deiksis lain yang disebut dengan deiksis jabaran. Terdapat beberapa bentuk jenis deiksis persona antara lain, deiksis persona pertama, kedua, serta ketiga dan dua bentuk deiksis sosial antara lain deiksis sosial absolut dan deiksis sosial relasional (Nurlaely (2014). Adanya persona pertama atau took utama dalam bentuk kategori rujukan pihak yang berbicara kepada dirinya atau sebuah kelompok yang terlibat dalam peristiwa tersebut, misalnya: saya, aku, daku, -ku, ku-. Kemudian persona kedua yaitu kategori rujukan pihak pembicara pada pendengar ataupun lebih yang hadir bersama dengan orang pertama, misalnya: engkau, dikau, kau, kamu, anda, kau-, dan -mu. Persona ketiga yaitu kategori jujukan orang yang bukan pembicara ataupun pendengar ujaran baik yang hadir ataupun tidak, misalnya: beliau, dia, ia, dan -nya. Keempat 
ialah persona gabungan antara persona pertama dan kedua, mislanya: kita. Sedangkan kelima yaitu persona pertama tanpa persona kedua, misalnya: kami. Keenam ialah persona kedua lebih dari satu, misalnya: kamu dan kalian. Ketujuh ialah persona kedua lebih dari satu, misalnya: mereka. Berikut ini adalah beberapa jenis deiksis persona yang terdapat dalam cerpen "Senyum Karyamin" karya Ahmad Tohari.

a. Deiksis Persona Pertama (orang pertama)

"Tidak. Beri aku minum saja. Daganganmu sudah ciut seperti itu. Aku tak ingin menambah utang."

"Makan, ya Min? Aku tak tahan melihat orang lapar. Tak usah bayar dulu. Aku sabar menunggu tengkulak datang. Batumu juga belum dibayarnya, kan?"

(halaman 4)

Kata $a k u$ pada tuturan percakapan diatas termasuk pada penggunaan deiksis persona pertama, karena berfungsi sebagai penujuk dan rujukan atau refrensinya bisa berpindahpindah berdasarkan pada kontekstuturannya (Marzuqi, 2016). Konteks tuturan terjadi ketika Saidah menawari makan Karyamin, namun Karyamin menolak karena ia tidak ingin menambah hutang dan melihat temannya rugi karenanya. Data tuturan deiksis persona tunggal (pertama) mempunyai bentuk konteks yang berpindah-pindah. Kata tunggal "aku" pada kalimat pertama mengacu pada Karyamin, dan kata "aku" yang kedua merujuk kepada Saidah.

b. Deiksis Persona Kedua (Orang Kedua)

"Jadi, kamu sungguh tak mau makan, Min?" tanya Saidah ketika melihat Karyamin bangkit.

"Tidak. Kalau kamu tak tahan melihat aku lapar, akupun tak tega melihat daganganmu habis karena utang-utangku dan kawan-kawan" (halaman 4)

Dalam percakapan antara Karyamin dengan Saidah tersebut terdapat adanya dua kata kaтu dan - ти. Kata kamu dan -mu dalam dialog di atas adala jenis deiksis persona kedua karena maksud dari kata tersebut pada kalimat pertama di tuliskan oleh Saidah merujuk pada Karyamin, sedangkan pada kalimat percakapan kedua di tuliskan oleh Karyamin merujuk pada Saidah.

\section{c. Deiksis Persona Kategori (Orang Ketiga)}

"Istrimu tidak hanya menarik mata petugas bank harian. Jangan dilupa tukang edar kupon buntut itu. Kudengar dia juga sering datang ke rumahmu bila kamu sedang keluar. Apa kamu juga percaya dia datang hanya menjual kupon buntut? Jangan-jangan dia juga menjual buntutnya sendiri!" (halaman 2)

Pada kalimat yang diucapkan oleh salah satu teman Karyamin tersebut terdapat adanya deiksis ketiga, yaitu adanya kata dia dan -nya. Maksud dari adanya kata dia dan -nya pada kalimat tersebut merujuk pada tukang edar penjual tukang buntut. Berdasarkan hal tersebut dapat dikatakan bahwa kata dia dan -nya pada kalimat tersebut ialah deiksis persona kata ganti jenis orang ketiga. 


\section{d. Persona Ketiga Lebih dari Satu}

"Mereka tertawa bersama. Mereka, para pengumpul batu itu, memang pandai bergembira dengan cara menertawakan diri mereka sendiri" (halaman 3)

Kata mereka pada kalimat tersebut termasuk kategori deiksis persona, dikategorikan pada deiksis persona ketiga lebih dari satu. Kata mereka pada kalimat tersebut merujuk pada kawankawan Karyamin tempat ia bekerja yaitu sebagai pengumpul batu.

\section{Deiksis Tempat dalam Tuturan Cerpen "Senyum Karyamin” Karya Ahmad Tohari}

Deiksis tempat atau deiksis ruang memiliki kaitan spesifikasi berdasarkan pada tempat relatife ke titik labuh dalam peristiwa tutur. Dalam pragmatik deiksis ruang berkaitan dengan adanya pemahaman ruang dan tempat yang digunakan pada lokasi tempat seorang penutur dengan mitra tuturnya melakukan pembicaraan. Tempat disebut dengan menjadi deiksis jika ruang atau tempat tersebut dapat terlihat dari lokasi orang-orang yang melakukan tindaktutur. Penentuan lokasi suatu objek membutuhkan sebuah titik pusat orientasi suatu ruang tempat terjadinya tuturan (Muhyidin, 2019). Adapun jenis-jenis deiksis tempat pada pengkajian pragmatik yaitu: lokatif (sana, sini, dan situ), demonstrative (itu, ini, begitu, dan begini), dan temporal (dini dan kini). Berikut ini merupakan deiksis hasil analisis deiksis tempat yang terdapat pada cerpen "Senyum Karyamin" karya Ahmad Tohari.

a. Deiksis lokatif

"Agak di hilir sana terlihat tiga perempuan pulang dari pasar dan siap menyeberang. Para pencari batu itu diam. Mereka senang mencari hiburan dengan cara melihat perempuan yang mengangkat kain tingi-tinggi” (halaman 2)

Pada kalimat diatas terdapat adanya deiksis tempat jenis lokatif yaitu adanya kata sana. Kata sana bermakna bahwa berlangsungnya adanya dialog, yaitu di sungai. Oleh sebab itu, adanya kata sana pada kalimat tersebut termasuk dalam deiksis jenis deiksis lokatif.

b. Deiksis temporal

"Jangan kira mereka datang setiap hari buat menagih setoran kepada istrimu.jangan percaya kepada anak-anak muda penjual duit itu. Pulanglah. Istrimu kini pasti sedang digodanya"

(halaman 2)

Pada kalimat diatas terdapat adanya kata kini. Adanya atau kini memiliki makna bahwa terjadinya suatu dialog atau percakapan tersebut pada lokasi saat itu juga dengan waktu saat itu juga yang mana merujuk pada rumah. Sehingga, adanya kata kini pada kalimat tersebut termasuk dalam deiksis dengan jenis deiksis temporal.

\section{Deiksis Waktu dalam Tuturan Cerpen "Senyum Karyamin” Karya Ahmad Tohari}

Pada tata bahasa deiksis memiliki nama lain yaitu sebagai adverbial waktu, yaitu kapan terjadinya pengungkapan kepada jarak waktu atau titik dipandang saat suatu terjadinya tuturan tersebut terjadi, atau lebih singkatnya saat seorang penutur melakukan ujaran. Waktu yang menunjukkan ketika suatu ujaran terjadi diungkapkan dengan adanya kata sekarang atau saat 
ini. Selain itu, untuk waktu-waktu berikutnya digunakan kata-kata seperti lusa, besok, kelak, nanti. Sedangkan waktu menunjukkan sebelum terjadinya ujaran dapat diungkapkan dengan adanya kata dahulu, ketika itu, kemarin, minggu lalu, dan tadi. Berikut ini adalah beberapa kalimat yang menunjukkan adanya deiksis waktu yang terdapat dalam cerpen "Senyum Karyamin" karya Ahmad Tohari.

"Dibayangkan istrinya yang sedang sakit harus menghadapi dua penagih bank harian. Padahal Karyamin tahu, istrinya tidak mampu membayar kewajibannya hari ini, hari esok, hari lusa, dan entah hingga kapan, seperti entah kapan datangnya tengkulak yang telah setengah bulan membawa batunya" (halaman 5)

Pada kalimat penggalan cerpen "Senyum Karyamin" tersebut terdapat adanya sebuah kata yang memiliki unsur deiksis waktu yaitu kata esok dan lusa. Adanya kata esok dan lusa menunjukkan waktu yang akan datang. Waktu esok dan lusa mengacu pada pemikiran Karyamin yang sedang bingung tidak tau entah kapan dapat membayar hutang-hutangnya kepada penagih bank tersebut, sedangkan uang upah ia bekerja sebagai pengumpul batu sampai saat itu belum juga diberikan oleh tengkulak.

\section{Deiksis Wacana dalam Tuturan Cerpen "Senyum Karyamin” Karya Ahmad Tohari}

Deiksis wacana yaitu menjelaskan tentang adanya hal yang memacu pada bagian tertentu yang terdapat pada suatu wacana yang sedang dikembangkan. Pada deiksis wacana tersebut terdapat adanya hal berkaitan antar penggunaan suatu ungkapan pada sebuah penuturan untuk mengacu pada bagian yang memiliki adanya penuturan tersebut. berikut ini adalah salah satu adanya deiksis wacana yang tedapat dalam cerpen "Senyum Karyamin" karya Ahmad Tohari.

"Suatu kali, Karyamin ingin membabat burung tersebut dengan pikulannya. Tetapi, niat itu diurungkan karena Karyamin sadar dengan mata yang berkunangkunang dia tak akan berhasil melaksanakan maksudnya" (halaman 3)

Pada kutipan di atas, terdapat adanya satu kata itu yang mengandung adanya unsur deikisis wacana. Kata itu pada kutipan tersebut termasuk dalam deiksis wacana karena pada kata itu mengacu pada penjelasan bahwa Karyamin mengurungkan niatnya untuk membabat burung yang bolak-balik melintas di atas kepalanya.

\section{Deiksis Sosial dalam Tuturan Cerpen "Senyum Karyamin” Karya Ahmad Tohari}

Pada deiksis sosial memiliki hubungan pada aspek-aspek kalimat yang menunjukkan adanya sebuah kenyataan tertentu mengenai tetang keadaan sosial saat adanya tindak tutur terjadi. Selain itu, deiksis sosial juga dapat dikatakan bahwa disamping mengacu pada keadaan suatu referen tertentu, memiliki adanya konotasi sosial tetentu, terlebih khususnya pada deiksis persona. Adapun hal yang menjadi patokan dalam deiksis sosial dapat disimpulkan berdasar pada masyarakat yang memiliki pengaruh pada peran seorang pendengar serta pada orang yang berbicara. Perbedaan tersebut ditunjukkan dalam upaya percakapan dengan menggunakan pemilihan kata saat melakukan tindak ujar. Berikut ini salah satu bentuk adanya deiksis sosial dalam cerpen "Senyum Karyamin" karya Ahmad Tohari.

"kamu menghina aku, Min?"

"Tidak, Pak. Sungguh tidak"

(halaman 6) 
Pada percakapan antara Pak Pamong dengan Karyamin tersebut termasuk pada deiksis sosial. Dalam kalimat percakapan tersebut menunjukkan adanya kejadian sosial seperti penggunaan bahasa Karyamin yang memanggil atasannya dengan panggilan Pak. Hal tersebut seperti pada umumnya dan seharusnya yang mana seorang anak buah atau asisten yang harus memanggil atasannya dengan lebih sopan atau lebih formal dibandingkan penggunaan bahasa saat sedang interaksi dengan rekan kerja sebaya yang lainnya. Sehingga, percakapan tersebut termasuk dalam bentuk deiksis sosial.

Adanya analisis mengenai deiksis pada cerpen "Senyum Karyamin" karya Ahmad Tohari tersebut selain digunakan untuk dapat membantu memahami makna dari apa yang akan disampaikan pada cerita, namun juga bertujuan untuk dapat digunakan dalam pembelajaran bahasa Indonesia. Pemanfaatan dari beberapa analisis deiksis novel "Senyum Karyamin" sebagai bahan ajar pembelajaran Bahasa dan Sastra Indonesia di SMA kelas X-XII dengan melihat Kompetensi Dasar yang sesuai dengan silabus kurikulum 2013 revisi 2017. Kompetensi Dasar menginterpretasi makna teks, menganalisis teks, memproduksi teks, menyunting teks, dan mengevaluasi teks. Selain hal tersebut, pemanfaatan karya sastra terlebih pada novel ataupun cerpen yang digunakan sebagai media pembelajaran ataupun bahan ajar dalam pembelajaran bahasa Indonesia guna untuk menambah minat baca serta kualitas keterampilan menulis siswa (Mustika, 2018). Dalam penggunaannya pada pembelajaran bahasa Indonesia, pembahasan tersebut dapat digunkan dalam materi deskripsi. Karena, dalam pengkajan ini harus dilakukan adanya pemahaman mengenai bacaan cerita yang akan dikaji kemudian setelah itu mampu untuk mampu menganalisis dari isi bacaan tersebut. Selain itu, diharapkan dari melalui cerpen "Senyum Karyamin" ini guru dapat menumbuhkan minat membaca sastra pada peserta didik serta menjadi peristiwa yang dapat direnungkan dan sebagai pengalaman peserta didik melalui adanya percakapan dalam cerita pendek tersebut (Rachmanita, 2016). Sehingga, dilakukan adanya analisis pada cepen tersebut selain untuk mengetahui deiksis pada cerita sesuai dengan kajian pragmatik akan tetapi juga dapat digunakan sebagai bentuk pembelajaran bahasa Indonesia tepatnya untuk siswa SMA.

\section{Simpulan}

Berdasarkan hasil dari analisis serta pembahasan mengenai penggunaan deiksis pada cerpen "Senyum Karyamn" karya Ahmad Tohari, peneliti menemukan beberapa jenis deiksis yang terdapat pada bacaan tersebut. Adapun beberapa jenis deiksis pada cerpen tersebut dan dilakukan analisis yaitu persona, tempat, waktu, wacana, dan sosial. Selain itu, dalam deiksis persona terdapat beberapa jenis deiksis persona di antaranya yaitu deiksis pesona pertama, deiksis pesona kedua, deiksis pesona ketiga, deiksis pesona pertama dengan pesona kedua, deiksis pesona pertama tanpa pesona kedua, serta deiksis pesona kedua lebih dari satu. Namun, yang terdapat dalam cerpen tersebut hanyalah deiksis pesona pertama (ditemukan adanya kata aku), deiskis persona kedua (ditemukan adanya kata kamu), deiksis persona ketiga (ditemukan adanya kata dia), serta deiksis persona ketiga lebih dari satu (ditemukan adanya kata mereka). Kemudian pada analisis berikutnya yaitu deiksis tempat. Pada deiksis tempat terdapat adanya tiga jenis deiksis tempat yaitu deiksis lokatif, demonstrative, dan temporal. Namun, dalam cerpen tersebut hanya dapat ditemukan adanya dua jenis deiksis tempat yaitu deiksis lokatif ditandai dengan ditemukannya adanya kata sana dan deiksis temporal ditandai dengan ditemukanya kata kini. Pada analisis ketiga yaitu deikisis waktu, ditandai dengan adanya kata lusa dan esok. Pada deiksis wacana, ditandai dengan adanya kata itu. Sedangkan pada deiksis sosial ditandai dengan adanya percakapan dengan bahasa formal antara tokoh Karyamin dengan atasannya. Tujuan dilakukannya kajian pragmatik dengan konsentrasi pada deiksis ini yaitu untuk mengetahui deiksis pada cerpen "Senyum Karyamin" agar pembaca lebih mudah untuk dapat memahami cerita di dalamnya. Selain itu, juga bertujuan untuk digunakan dalam kegiatan 
pembelajaran bahasa Indonesia dalam materi memahami bacaan serta menganalisis bacaan ataupun menceritakan kembali bacaan cerita pendek.

\section{Referensi}

Agustiyan, D. (2012). Analisis deiksis dalam novel Lintang Panjer Rina karya Daniel Tito dan pembelajarannya di SMA. ADITYA-Pendidikan Bahasa dan Sastra Jawa, 1(1).

Fitriani, Maman, M., \& Aziz, A. (2019). Penggunaan deiksis dalam pembelajaran bahasa Indonesia siswa kelas XI SMA Negeri 11 Makasar. (Diploma Thesis). Universitas Negeri Makassar.

Jayati, P. (2018). Deiksis sosial dalam novel Rembulan Tenggelam Di Wajahmu karya Tere Liye, Suatu Kajian Pragmatik. Skripsi. Universitas Negeri Jakarta, Jakarta.

Junianto, D. (2010). Pemakaian deiksis sosial dalam novel Laskar Pelangi karya Andrea Hirata. Skripsi, Universitas Muhammadiyah Surakarta.

Kusumawardani, P. (2017). Deiksis persona, tempat, dan waktu dalam novel "Pulang" Karya Tere Liye (Kajian Pragmatik) dan relevansinya dengan pembelajaran bahasa Indonesia Di SMA. Skripsi. Universitas PGRI Yogyakarta.

Megawati, M., Ana, H., \& M. Yazid. (2019). Penggunaan deksis dalam cerita rakyat Bugis yang diterjemahkan dalam bahasa Indonesia. Jurnal Pendidikan Bahasa, 8(2).

Merentek, S. H. (2016). Deiksis dalam film Cinderella: Analisis pragmatik. Jurnal Elektronik Fakultas Sastra Universitas Sam Ratulangi, 2(1).

Muhyidin, A. (2019). Deiksis dalam novel Daun Yang Jatuh Tak Pernah Membenci Angin karya Tere Liye dan skenario pembelajarannya di SMA. Metalingua, 17(1), 45-46.

Mustika, R. R. (2018). Deiksis dalam novel" Ayah" karya Andrea Hirata serta pemanfaatannya sebagai bahan ajar pembelajaran bahasa dan sastra Indonesia di SMA. Skripsi. Jakarta: FITK UIN Syarif Hidayatullah Jakarta.

Nadzifah, Z. N., \& Utomo, A. P. Y. (2020). Tindak tutur perlokusi pada dialog film "Keluarga Cemara" karya Yandy Laurens. Dinamika, 3(2), 43-53.

Narayukti, N. N. D. (2020). Analisis dialog percakapan pada cerpen kuda putih dengan judul "surat dari puri": Sebuah kajian pragmatik "deiksis". Jurnal Pendidikan dan Pembelajaran Bahasa Indonesia, 9(2), 86-94.

Nurlaely, A. 2014. Deiksis Persona Dan Sosial Pada Novel Little Women Karya Louisa May Alcott: Kajian Pragmatik (Doctoral Dissertatuon).

Purwo, B.K. (1984). Deiksis dalam bahasa Indonesia. Balai Pustaka.

Purwoningrum, S. M. (2013). Kajian pragmatik naskah gurindam Dua Belas karya Raja Ali Haji. Suluk Indo, 2(3), 279-293.

Rachmanita, A. A. (2016). Deiksis sosial dalam novel sang pemimpi karya Andrea Hirata dan implikasinya terhadap pembelajaran bahasa dan sastra Indonesia di SMP. Skripsi. UIN Syarif Hidayatullah Jakarta.

Rahardi, R. K. (2005). Pragmatik: Kesantunan imperatif bahasa Indonesia. Erlangga.

Rohmadi, M. (2014). Kajian pragmatik percakapan guru dan siswa dalam pembelajaran bahasa Indonesia. Paedagogia, 17(1), 53-61.

Setyawati, E. (2013). Analisis nilai moral dalam novel Surat Kecil untuk Tuhan karya Agnes Davonar (Pendekatan Pragmatik). Skripsi. Yogyakarta: UNJ.

Suparno, D. (2015). "Deiksis" dalam Kumpulan Cerpen Al-Kabuus Tinjauan Sosiopragmatik. Buletin Al-Turas, 21(2), 343-364.

Syahrul, R., Syahrul, R., \& Nasution, B. (2012). Deiksis sosial dalam novel Negeri 5 Menara karya A. Fuadi: Suatu tinjauan pragmatik. Jurnal Bahasa dan Sastra, 1(1), 84-91.

Tohari, A. (1995). Kumpulan cerpen Senyum Karyamin. Jakarta: Gramedia Pustaka Utama.

Tologana, W. (2016). Deiksis dalam novel Assalamualaikum Beijing karya Asma Nadia. Skripsi. Manado: Universitas Sam Ratulangi. 
Wicaksono, A. J., Winarni, R., \& Rohmadi, M. (2019). Deiksis persona, tempat, dan waktu dalam novel Bumi Manusia karya Pramoedya Ananta Toer: Kajian pragmatik dan relevansinya dengan pembelajaran bahasa Indonesia di sma. In Prosiding Seminar Nasional "Inovasi Pembelajaran Bahasa Indonesia di Era Revolusi Industri 4.0" (pp. 228-230).

Yuliana, R., Rohmadi, M., \& Suhita, R. (2013). Daya pragmatik tindak tutur guru dalam pembelajaran bahasa Indonesia pada siswa sekolah menengah pertama. BASASTRA, 1(2), 280-293. 